\section{AML 02}

HIGH-DOSE CYTOSINE ARABINOSIDE AND MITOXANIRONE: A HIGHLY EFFECTIVE REGIMEN IN REFRACTORY ACUTE MYELOID LEUKEMIA W. Hiddemann, H. Kreutzmann, K. Straif, W.D. Ludwig, R. Dorihuijsen-Ant; E. Lengfelder and Th. Büchner

Based on the promising results of monotherapy trials with HD-AraC and Mitox. in refractory AML a multi-institutional study was initiated at 6 centers in Germany to assess the toxicity and antileukemic efficacy of the two drug combination. All patients were recruited from the first Iine multicenter trial by the German AML Cooperative Group. Refractoriness was defined by: 1 . primary resistance against two TAD-9 induction courses; 2 . early relapse within the first 6 months; 3. relapse after 6 months with non-response against one additional TAD-9 cycle; 4 . second and subsequent relapses. Treatment consisted in $\mathrm{HD}-$ AraC $3 \mathrm{~g} / \mathrm{m}^{2}$ every 12 hrs on days 1 - 4. Mitox. was started at $12 \mathrm{mg} / \mathrm{m}^{2} / \mathrm{d}$ on days 3,4 and 5 and escalated in subsequent cases to 4 and 5 doses of $10 \mathrm{mg} / \mathrm{m}^{2}$ d. on days $2-5$ and $2-6$ respectively.

From 30 patients entering the trial so far, 27 are presently evaluable. 14 patients achieved a CR (52)ㅜㅇ while a PR was obtained in 1 additional case. 9 patients died within the first 4 weeks of therapy because of infectious complications, in 3 cases the leukemic cell population persisted or recovered after the end of therapy. Except for one death possibly related to acute cardiomyopathy, toxicity was mila to moderate consisting in nausea, vomiting, mucositis and diarrhea. These data indicate a high anti-leukemic activity of HD-AraC and Mitox. in combination in refractory AML and strongly suggest to apply this regimen at earlier stages of AML therapy.

\section{AML 04}

ABNORMAL PRODUCTION AND RELEASE OF FERRITIN BY IMMATURE MYELOID CELLS IN LEUKEMIA.

H. From, E. Aulbert

Ferritin concentration in serum and in levkemic cells was investigated in 163 adults with different types of lekkemia. The results are sumarized in table 1. Extremely high serum ferritin concentrations were found in patients with acute inmature niveloblastic leukemia (M1) before treatment. In patients with the more differentiated forms of acute letkemia (M3-M6) serum ferritin levels were found to be significantly lower. During tumor regression high pretreatment serum ferritin levels decreased and reached nomal values in complete remission. Investigation of the intracellular ferritin concentration showed a dinect correlation betwen the levels of serun ferritin and the amount of ferritin witnin the levke mic cells. In patients with chronic myeloid levkemia during the chronic phase we found nomal serum ferritin concentrations, whereas myeloid blast crisis was associated with higily raised serm ferritin levels. In cases of myelamonocytic type or lymphatic type of blast crisis a significantly less increament of serum ferritin concentration was secn. inere was also a direct correlation between serun ferritin concentration and intracellular ferritin content of myeloid cells in the chronic phase and in myeloid blast crisis.

These findings indicate that inmature myeloid cells in acute myeloblastic leukenia and in blast crisis of chronic myeloid leukenia produce and release ferritin at a very high rate. Thus, in these cases serum ferritin can be used as parameter in monitoring the activity of the disease.

\begin{tabular}{|c|c|c|c|}
\hline Table 1: & $\begin{array}{l}\text { Classi- } \\
\text { fication }\end{array}$ & $\begin{array}{l}\text { Serum ferritin } \\
\text { concentration }\end{array}$ & $\begin{array}{l}\text { Intracell. ferritin } \\
\text { concentration }\end{array}$ \\
\hline Myeloblastic L. & $\begin{array}{r}F A B-M 1 \\
M 2\end{array}$ & $\begin{array}{l}2235 \pm 870 \mathrm{ng} / \mathrm{ml} \\
1355 \pm 532 \mathrm{ng} / \mathrm{ml}\end{array}$ & $72 \pm 16 \mathrm{fg} / \mathrm{cell}$ \\
\hline Pran & M3 & $565 \pm 135 \mathrm{ng} / \mathrm{ml}$ & \\
\hline tic $\mathrm{L}$. & M4 & $450 \pm 252 \mathrm{ng} / \mathrm{ml}$ & $9 \pm 4 \mathrm{fg} / \mathrm{cell}$ \\
\hline Monocytic L. & M5 & $463 \pm 254 \mathrm{ng} / \mathrm{ml}$ & \\
\hline Erythroletukenia & M6 & $598 \pm 145 \mathrm{ng} / \mathrm{ml}$ & $\Delta \pm 2 \mathrm{fo} / \mathrm{Cel}$ \\
\hline $\begin{array}{l}\text { Akute Iympnatic L. } \\
\text { Chronic myeloid L. }\end{array}$ & & $84 \pm 51 \mathrm{ng} / \mathrm{ml}$ & $3 \pm 2 \mathrm{fg} / \mathrm{cell}$ \\
\hline & (b & $2180 \pm 867 \mathrm{ng} / \mathrm{ml}$ & $52 \pm 12 \mathrm{fg} / \mathrm{cell}$ \\
\hline
\end{tabular}

St. Barbara-Hospital, Imere Abt. , 4390 Gladheck, Barharastr. 1,GFR

AML 05

HIGH DOSE ARA-C AND VP16 IN TREATMENT OF REFRACTORY OR RELAPSING ACUTE LEUKEMIA

M. Freund, H. Link, H. Diedrich and H. Poliwoda.

We treated 13 patients ( $9 \mathrm{~m}, 4 \mathrm{f}$ ) with AraC 3 $\mathrm{gr} / \mathrm{m}^{2}$ twice daily $\mathrm{d} 1-6$ and $\mathrm{VP} 16$ $100 \mathrm{mg} / \mathrm{m}^{2}$ d 1-5: 1 ALL (L1), 12 AML ( 3 M1, 7 M2, 2 M4). Median age was 40 yrs $(18-62) .11$ courses have been administered for induction. One of these patients had primary refractory leukemia (group 1), 5 were in refractory 1st or 2nd relapse (group 2), 5 more had 1st, 2nd or $3 r d$ relapse (group 3) with a median preceeding remission of 5 mo (3-12 mo). Consolidation therapy was not constantly given.

Treatment results were $8 / 11$ CR ( 4 group 2,4 group 3), 1/11 MR (group 2), 1/11 NR (group 1), $1 / 11$ early death (group 3). Median $\mathrm{CR}$ duration was $1.5+$ mo. Hematotoxicity was severe in induction with mean duration of granulocytopenia below $500 / \mathrm{cmm}$ for 24,3 d (beginnig at d 5,2 ; $s=13,0$ ) and thrombocytopenia below $20000 / \mathrm{cmm}$ for $18,0 \mathrm{~d}$ (beginning at $d 6,9 ; \mathrm{s}=7,6$ ). 5 courses were administered for consolidation. Hematotoxicity of consolidation therapy was severe too: Granulocytopenia lasted for $19,3 \mathrm{~d}$ $(s=2,5)$ beginning at d 9,0, thrombocytopenia for $14,0 \mathrm{~d}(\mathrm{~s}=1,0)$ beginning at $d 10,8$. There were 2 treatment related deaths due to sepsis in aplasia. Moderate hepatic toxicity was observed as well as bleeding tendency, mucositis, diarrhea, erythema, other infections, conjunctivits but no cerebellar toxicity. We conclude that combination of high dose AraC and VP16 is a powerful though toxic induction regimen.

Abteilung Hämatologie/Onkologie, Medizinische Hochschule Hannover, Konstanty Gutschowstr. 8, D-3000 Hannover 61 